\title{
METHODOLOGICAL INSTRUMENTS FOR FORMING THE MARKETING STRATEGY OF AGRICULTURAL PRODUCTION ECOLOGIZATION
}

\author{
Mariya BAGORKA ${ }^{1}$ \\ Dnipropetrovsk State Agrarian and Economic University, Ukraine
}

\begin{abstract}
The purpose of the article is the investigation of the nature, objectives, and strategic categories of ecologization marketing strategy, development of algorithm of this strategy and determination of environmental, economic, and ecological instruments of implementation of this strategy in the agricultural sector. Methodology. The basis of the formation of a marketing strategy for the ecologization of agrarian production is the systematic approach, which is based on the existence of implementation mechanisms that ensure system consistency, its purposefulness; interdependence; and complexity of its elements, which determines the integrity of the system; all tasks that execute individual elements of the system are interconnected; system elements and their associated actions have a certain subordination that builds a hierarchy; the system changes under the influence of specific factors, which determines its dynamism; the ability of the system to adapt to the variability of the external environment, while not losing its own individuality. Methods for strategic analysis of macro- and micro-environment factors were used to form the marketing strategy of ecologization. This process involves an analytical evaluation of the parameters of the external and internal environment with the help of general scientific and applied methods of strategic analysis. Results. The article explored the ecologization strategy, presented its objectives in the field of agriculture, the basic categories of strategic directions and implementation of ecologization marketing strategies. An algorithm of environmental marketing strategies in agricultural production is developed, environmental, economic and environmental and economic tools to implement them are determined. Practical implications. It is determined that marketing strategy of ecologization of agrarian production is a strategy of innovative development that can solve problems of economic growth, an increase of competitiveness of the agrarian industry, provide a high quality of life, national security, environmental protection, and high technical level of agricultural production in Ukraine. Value/originality. This marketing strategy is capable of ensuring the principle of unity for economic and ecological processes in the management of agricultural production and promoting radical restructuring of the relationship of the production process from the environment. This strategy takes into account the environmental factor in the economic activities of agrarian enterprises and aims at creating environmental products and services in agricultural production.
\end{abstract}

Key words: marketing strategy of ecologization, agrarian production, strategic categories, strategic analysis, marketing researches, ecological-economic mechanism.

JEL Classification: M31, O13, Q13

\section{Introduction}

The particularly relevant issue of the rational and sustainable use of natural resources is presented in the agricultural sector, which is the most sensitive contact zone in the system of mutual economic and environmental interests of humanity. For many years, in agriculture, a destructive effect on the environment increased.

This necessitated fundamentally new vision of capabilities ensuring the environmental and economic balance in the agribusiness.
Today ecological improvement of economic activity is important; it suggests the ecological balance between the consumption of natural resources, agriculture, and the possibility of recovery of the environment.

Problems in the field of agriculture and improvement of its competitiveness can be addressed through effective strategies and mechanisms for innovation. Such an innovation strategy, in our opinion, should be the ecologization marketing strategy of agriculture that ensures high quality of life, national security, environmental protection,

Corresponding author:

${ }^{1}$ Department of Marketing, Dnipropetrovsk State Agrarian and Economic University.

E-mail: Masha010574@gmail.com 
and high technical level of agricultural production in Ukraine.

To date, the transition to new agribusiness systems is a complex process of developing a new strategy for innovation development, which is formed in parallel with the existing strategies. The marketing strategy of environmentalizing agrarian production is, in our opinion, an innovative strategy that allows integration of environmental priorities in the strategy of economic development.

It is the marketing strategy for environmentalizing agrarian production to be a link between agrarian enterprises, market, and society, as well as to ensure the formation of public opinion and the market environment.

The formation of an effective marketing strategy for the environmentalization of agrarian production, first of all, is necessary for a full supply of food security of the country, as well as the transformation of the agrarian complex into a highly productive branch of the national economy, therefore, the study of methodological approaches to the development of this strategy is relevant and practically significant.

However, the problem of the formation of a marketing strategy for the environmentalization of agrarian production is still not sufficiently investigated in the theoretical as well as practical aspects. There is a need to deepen theoretical research and methodological developments associated with the formation of a marketing strategy for the environmentalization as a component of the ecological and economic mechanism for managing agrarian production.

\section{The essence and purpose of the marketing strategy of ecologization of agrarian production}

Ecologization is a direction of development of agriculture, based on the development of ecological methods of management, provides an extended reproduction of natural and human resources through the formation of sustainable ecological and economic systems aimed at increasing the volume of production of competitive products (Tkachuk, 2014).

It is the marketing strategy of ecologization that can ensure the principle of unity of economic and ecological processes in the management of agrarian production and will contribute to a radical restructuring of the relationship of the production process with the natural environment.

The main objective of the marketing strategy is to ecologize agrarian production at different levels of management:

Guaranteed to ensure a high-quality and safe nutrition of the population in order to preserve the gene pool, to support the health of the nation, and to increase the longevity of life. Ensuring environmental management of agriculture and protecting the natural environment.

Raising the competitiveness of agriculture through the modernization of agrarian production, innovative development of agribusiness, the introduction of information technologies, support for the production of new types of agricultural products, support for the cooperation of agricultural producers.

Production of environmentally sound agricultural products, ensuring its competitiveness in the domestic and foreign markets.

The main purpose of environmental marketing at national and regional levels is to create conditions for economic entities, in which they are interested in maintaining and restored natural resources while implementing innovative approaches in their work.

\section{Stages of the formation of the marketing strategy of ecologization}

The basis of the formation of a marketing strategy for environmentalization of agricultural production is the main strategic categories that are considered the basis of strategic marketing.

The process of developing an ecologization marketing strategy should be begun with the identification of key industry issues: economic, political, social, technological, and environmental, which need a strategic analysis.

With forming ecologization strategies for the agricultural production, we propose the use of key strategic categories: mission statement, goals and objectives; strategic analysis of macro and micro factors; choice of priority strategic directions, forming tools for the implementation of this strategy; assessment and monitoring of its implementation.

The initial stage in developing the marketing strategy of environmentalization is the definition of the mission, which is what is the main philosophy, the main purpose of the existence of this strategy (Kudenko, 2012).

In our opinion, the mission of the marketing strategy of ecologization is to ensure balanced development of the agrarian sector of the economy, that is, to maintain a balance between the economic system and the natural environment, which results in improving the long-term economic, social and environmental welfare of the society. With the help of this strategy, it is possible to solve the contradiction between the economic interests of producers and the preservation of the environment, that is, the provision of environmentally safe living conditions of the population.

The main objective of the marketing strategy of ecologization of agrarian production at the state and regional levels is to create economic conditions for economic entities, in which they will be interested in preservation and restoration of natural resources potential when introducing innovative approaches in their activities. 
At the level of business entities, the main objective of the marketing strategy of ecologization of agrarian production is the development of economic organizationalandeconomicmechanism ofmanagement of an agrarian enterprise with the application of its main components: planning, stimulation (motivation), an organization of management, control, etc. At the same time, it is necessary to orient production to meet the ecological needs of consumers.

The external environment, in which there are domestic farms, is qualitatively different, escalating competition in the market, increasing its degree of uncertainty, there are unforeseen risk factors. That is why the work on the strategy begins with a comprehensive study of the market situation in the industry (Danylyshyn, 2008).

At the stage of strategic industry analysis, a special attention should be paid to the assessment of environmental and economic potential because of resource development concepts of marketing strategy changes the vector of reactive (reacting on changes in the environment) to proactive (prevention events) (Andreeva, 2009). Therefore, an essential step in the formation of a marketing strategy of the greening of agriculture, we believe it is providing strategic relevance, providing coordination of resources and production capacity with market conditions.

The marketing strategy of environmentalizing agrarian production should be oriented towards the formation of sustainable competitive advantages. Therefore, the results of the assessment of environmental factors are a prerequisite for the formation of a complex information and analytical support of marketing management

Marketing strategy for ecologizing agrarian production includes instruments of ecological and economic management. The traditional system of tools includes product, price, promotion, and distribution, that is, the main components of the $4 \mathrm{P}$ complex; from the consumer's point of view - needs, costs, communication, and convenience. In contrast to the traditional system of tools of the marketing complex, the environmental strategy takes into account the environmental aspects of the marketing strategy (Kuchmiov, 2014).

The main requirements for the formation of a marketing strategy for the environmentalization of agrarian production are the following:

1) the reality, which involves its compliance with the situation, objectives, market, production and resource factors, experience and skills of the management system in the industry;

2) logical, internal integrity and consistency of individual elements;

3) compatibility with the external environment, providing an opportunity to interact with it;

4) risk is justified;

5) focus on the formation of sustainable competitive advantages.
When forming this strategy, it is necessary to understand that it is not just about the one-time use of innovations to achieve instant advantages but about a continuous, detailed planned strategic innovation development that forms new methods and controls, transforming the intensive introduction of innovation processes into the factor of economic growth in the industry.

\section{Economic and environmental management methods in agrarian production}

The implementation of the marketing strategy of the greening of agricultural production by using environmental-economic management mechanism, based on up measures allow, in our opinion, changing the format of relations between production and the environment towards sustainable use, reproducing agricultural systems.

Economic management methods in the ecologization of nature management should include the creation of economic conditions that would encourage land users to achieve better results in their work.

Economic management methods of agricultural production include:

- providing favourable short- and long-term loans to implement projects of ecologically safe and economically effective technologies;

- partial or complete exemption from income tax in the case of funds for the purchase of ecologically safe fixed assets;

- preferential taxation and crediting for agricultural enterprises producing ecologically safe products and environmentally friendly production;

- ecological adaptation of tax and price systems;

- encouraging employees of enterprises producing ecologically clean products and compliance with environmental legislation (soil fertility, quality standards of production, improvement of environmental parameters);

- development of the possible variants for the refund of damages related to crop shortfalls in the production of ecologically safe products.

Economic instruments include promotional leverage, the use of preferential taxation and credit, and price incentives of environmental activities.

Environmental management tool provides certification and labelling of ecological products, which prove that they comply with the identified facilityspecific regulations. The process of certification and standardization should be conducted according to international standards, adapted to the conditions of Ukraine (Sadchenko, 2002).

Ecological and economic tools, in our opinion, are the part of an environmental marketing and include:

- production of ecologically safe agro products and its environmental positioning; 
- pricing taking into account environmental costs;

- development of ecologically safe products market, which is based on international standards for ecological agricultural production;

- distribution of ecologically safe food products;

The state should perform important functions to stimulate agricultural growth, social protection, the rise of the quality oflife. This priority role of state regulation of agriculture, in any case, does not reduce the importance of market self-regulation. Mechanisms of state actions should focus on supporting private initiatives aimed at the development of new technologies, stimulate innovative activity in rural areas (Shkuratov, 2012).

Marketing is a tool for environmental management and can be implemented by forming appropriate environmentally focused strategies, which can ensure the principle of unity of economic and ecological processes in the management of agricultural production and promote radical restructuring of relations of production with the environment.

Formation of strategy of environmental marketing in the agricultural sector, in our opinion, is the integration of all administrative functions that also contribute to the ecologization of agricultural production, allocation, planning and forecasting of business initiatives for the investment basis, which is linked to production, formation, and stimulate demand for eco-friendly products, agricultural products, and ecosystem services.

\section{Conclusions}

It is established that marketing strategy of ecologization of agrarian production is a strategy of innovative development that can solve problems of economic growth, increase the competitiveness of the agrarian industry, provide a high quality of life, national security, environmental protection, and high technical level of agricultural production in Ukraine.

When forming a marketing strategy for environmentalizing agrarian production use the main strategic categories: definition of mission, goals and objectives; strategic analysis of factors of macro- and micro-environment; the choice of priority strategic directions, the formation of tools for implementing this strategy; evaluation and control over its implementation.

The main components of the marketing strategy of environmentalization of agrarian production include: commodity strategy: price strategy; sales strategy; promotion strategy.

When implementing the marketing strategy of ecologization of agrarian production, a combination of ecological and economic instruments at the state regulation of ecological and economic components is important.

\section{References:}

Andreeva N. (2009). Marketing ecological strategies as a conceptual basis of sustainable development of the enterprise. Mechanism of regulation of economy, 3 T. 2: 119-125.

Danylyshyn B. \& Lubchenko O. (2008). The marketing strategy of regional food market. Bulletin of the National Academy of Sciences of Ukraine, 5: 12-18.

Kudenko N. (2012). Principles of strategic marketing. Ministry of Education and Science of Ukraine, State University "Vadim Hetman Kyiv National Economical University", 14 Part 1: 125-133.

Kuchmiov A. (2014). Ecological marketing tools in the context of ensuring environmental safety. Problems of material culture: 84-89.

Sadchenko E. (2002). Principles and concept of ecological marketing. Astroprint: 400.

Shkuratov O. (2012). Organizational and legal mechanism of ensuring of ecological and economic security of agricultural production. Agroecology magazine, 1: 10-14.

Tkachuk V. (2014). Ecologization of production as a priority of the process of diversification of agrarian enterprises. Effective economy. 4. [Electronic resource]. - Mode of access: http://www.economy.nayka.com.ua

\section{Мария БАГОРКА}

\section{МЕТОДОЛОГИЧЕСКИЙ ИНСТРУМЕНТАРИЙ ПРИ ФОРМИРОВАНИИ МАРКЕТИНГОВОЙ СТРАТЕГИИ ЭКОЛОГИЗАЦИИ АГРАРНОГО ПРОИЗВОДСТВА}

Аннотация. Целью работы является исследование сущности, целей и стратегических категорий маркетинговой стратегии экологизации, разработка алгоритма данной стратегии и определение экологических, экономических и экологических инструментов реализации стратегии экологизации в сельскохозяйственном секторе. Методология. Основой формирования маркетинговой стратегии для экологизации аграрного производства является системный подход, основанный на существовании механизмов реализации, обеспечивающих согласованность системы, ее целеустремленность; взаимозависимость и сложность ее элементов, которые определяют целостность системы; все задачи, выполняющие отдельные элементы системы, взаимосвязаны; системные элементы и связанные с ними действия имеют определенное подчинение, которое строит иерархию; система изменяется под влиянием 
Vol. 3, No. 4, 2017

определенных факторов, определяющих ее динамизм; способность системы адаптироваться к изменчивости внешней среды, не теряя при этом своей индивидуальности. Были использованы методы стратегического анализа макро- и микро-факторов окружающей среды для формирования маркетинговой стратегии экологизации. Этот процесс включает аналитическую оценку параметров внешней и внутренней среды с помощью общих научных и прикладных методов стратегического анализа. Результаты. В статье рассмотрена стратегия экологизации, представлены ее цели в области сельского хозяйства, выделены основные категории стратегических направлений и реализация маркетинговых стратегий экологизации. Разработан алгоритм стратегий экологического маркетинга, в сельскохозяйственном производстве, определены экологические, экономические и экологические и экономические инструменты для их реализации. Практическое значение. Установлено, что маркетинговая стратегия экологизации аграрного производства это стратегия инновационного развития, которая может решать проблемы экономического роста, повышения конкурентоспособности аграрной промышленности, обеспечения высокого качества жизни, национальной безопасности, охраны окружающей среды и высокого технического уровня сельскохозяйственного производства в Украине. Значение/оригинальность. Предложенная маркетинговая стратегия экологизации аграрного производства способна обеспечить принцип единства для экономических и экологических процессов в управлении сельскохозяйственным производством и способствовать радикальной перестройке отношений производственного процесса от окружающей среды. Главной особенностью данной стратегии является то, что она учитывает экологический фактор в экономической деятельности аграрных предприятий и направлена на создание экологических продуктов и услуг в сельскохозяйственном производстве. 